doi:10.4149/neo_2015_062

\title{
New perspectives in diagnosis of gynaecological cancers: Emerging role of circulating microRNAs as novel biomarkers
}

\author{
Minireview
}

L. ZAVESKY ${ }^{1, *}$, E. JANDAKOVA², R. TURYNA³ , L. LANGMEIEROVA ${ }^{4}$, V. WEINBERGER ${ }^{5}$, L. MINAR ${ }^{5}$, M. KOHOUTOVA ${ }^{6}$

${ }^{1}$ Institute of Biology and Medical Genetics, First Faculty of Medicine, Charles University Prague and General University Hospital in Prague, Albertov 4, CZ-128 00 Prague 2, Czech Republic; ${ }^{2}$ Institute of Pathology, University Hospital Brno, Obilni trh 11, CZ-625 00 Brno, Czech Republic; ${ }^{3}$ Institute for the Care of Mother and Child, Podolske nabrezi 157, CZ-147 00, Prague 4, Czech Republic; ${ }^{4}$ Faculty Transfusion Centre, General University Hospital in Prague, U Nemocnice 2, CZ-128 08 Prague, Czech Republic; ${ }^{5}$ Department of Obstetrics and Gynaecology, University Hospital Brno, Obilni trh 526/11, CZ-602 00 Brno, Czech Republic; ${ }^{6}$ Institute of Biology and Medical Genetics, First Faculty of Medicine, Charles University Prague and General University Hospital in Prague, Albertov 4, CZ-128 00 Prague 2, Czech Republic

*Correspondence: ludek.zavesky@gmail.com

Received January 2, 2015 / Accepted March 18, 2015

Early diagnosis is a prerequisite of the more successful treatment of cancer. In gynaecological cancers, such as ovarian, endometrial and cervical cancers, the recent efforts are aimed at finding novel diagnostic biomarkers to help reduce the worldwide health burden associated with these cancers. In this review, we focus on the recent research progress in circulating, particularly cell-free microRNAs expression achieved in ovarian, endometrial and cervical cancers showing an opportunity to find novel diagnostic biomarkers for these malignant diseases. With the onset of microRNAs investigations showing their diagnostic potential in many diseases, their role in gynaecological cancers has been examined as well. However, similarly as in many other diseases, the vast majority of research on microRNAs expression has been dealing with tissue samples and cell lines. Recently, as the novel approaches focused on cell-free microRNAs expression have emerged, several studies identified their potential diagnostic and prognostic value in gynaecological cancers using blood, serum/plasma or urine samples. More research will be needed to establish circulating and extracellular microRNAs as the novel diagnostic markers for gynaecological malignancies. Inconsistency of results across the studies due to technical and biological variation, and a low number of this kind of investigations are the main potential pitfalls remaining to be resolved.

Key words: cervical cancer, circulating microRNA, diagnosis, endometrial cancer, ovarian cancer, microRNA

Diagnosis of cancer within the early stages of the disease progression is usually associated with a better response to treatment and eventually results in an improved survival of patients. In ovarian cancer, the most deadly gynaecological cancer, the early detection during stages I and II leads to a $60-90 \%$ 5-year survival of patients, however diagnosis in the stages III and IV results in significantly decreased survival rate about $33 \%$, with the worst survival rate (19\%) observed for stage IV [1]. In the USA, the diagnosis of localized stages results in a $92 \%$ survival, while diagnosis in regional stages accounts for a $72 \%$ survival. Survival rates further drop to $27 \%$ in diagnosis of distant stages. On average, a 5-year survival rate of $44 \%$ is reported for ovarian cancer patients [2]. More than two thirds of ovarian cancer cases are diagnosed in advanced stages typically associated with a resistance to chemotherapy treatment and a disease recurrence. As a result, this eighth most common female cancer worldwide occupies the sixth position in estimated deaths for female cancer in developed countries [3].

Epithelial ovarian cancer (EOC) is traditionally divided into several subtypes due to an extensive histopathological heterogeneity: serous (most common, $\sim 70 \%$ of EOC), mucinous, 
endometrioid, clear cell, transitional cell, or their combinations (mixed) types are recognized [4]. Based on molecular traits, the most recent views suggest treating EOC either as type 1 (early stages, indolent clinical course and rare TP53 mutations), or type 2 (advanced stages, aggressive, genetically highly unstable with $\sim 80 \%$ frequency of TP53 mutations) $[5,6]$. In ovarian carcinogenesis, etiopathological processes may be interrelated within the parts of gynaecological tract (see [7]). In a search of a place of EOC origin, increasing evidence suggests the clear cell and endometrioid carcinomas (type 1) may arise from endometriosis. The presumable origin of mucinous tumors (type 1) is more questionable, with implicated roles of ovarian teratomas, surface epithelial inclusions, endometriosis, Brenner tumors, or endocervix. Low-grade serous carcinomas are thought to evolve from benign serous cystadenomas through serous borderline tumors (see [6]). High-grade serous carcinomas (type 2) have been suggested to originate from the epithelium of the fallopian tube, or may have truly ovarian origin through ovarian metaplasia of the ovarian mesothelium or ectopic Müllerian tissue (endometriosis, endosalpingiosis) [4]. Cancer stem cells and processes of epithelial to mesenchymal (and vice versa) transition are further implicated in ovarian carcinogenesis. They may play a role in above mentioned processes of the development and progression of ovarian cancer [7-10].

Cervical cancer is the third most common female cancer worldwide [3]. This malignancy is mainly considered as a consequence of the long-term infection with human papillomavirus (HPV) resulting in incorporation of viral DNA into host DNA and induction of oncogenic transformation [11]. In developing countries, the cervical cancer represents the second most deadly female cancer $(242,000$ estimated deaths) in contrast to developed countries where most of the deaths $(64,500)$ from gynaecological cancers are attributed to ovarian cancer [3].

Endometrial cancer, however, is the most common gynaecological cancer, the sixth most common female cancer worldwide and the fourth most often diagnosed female

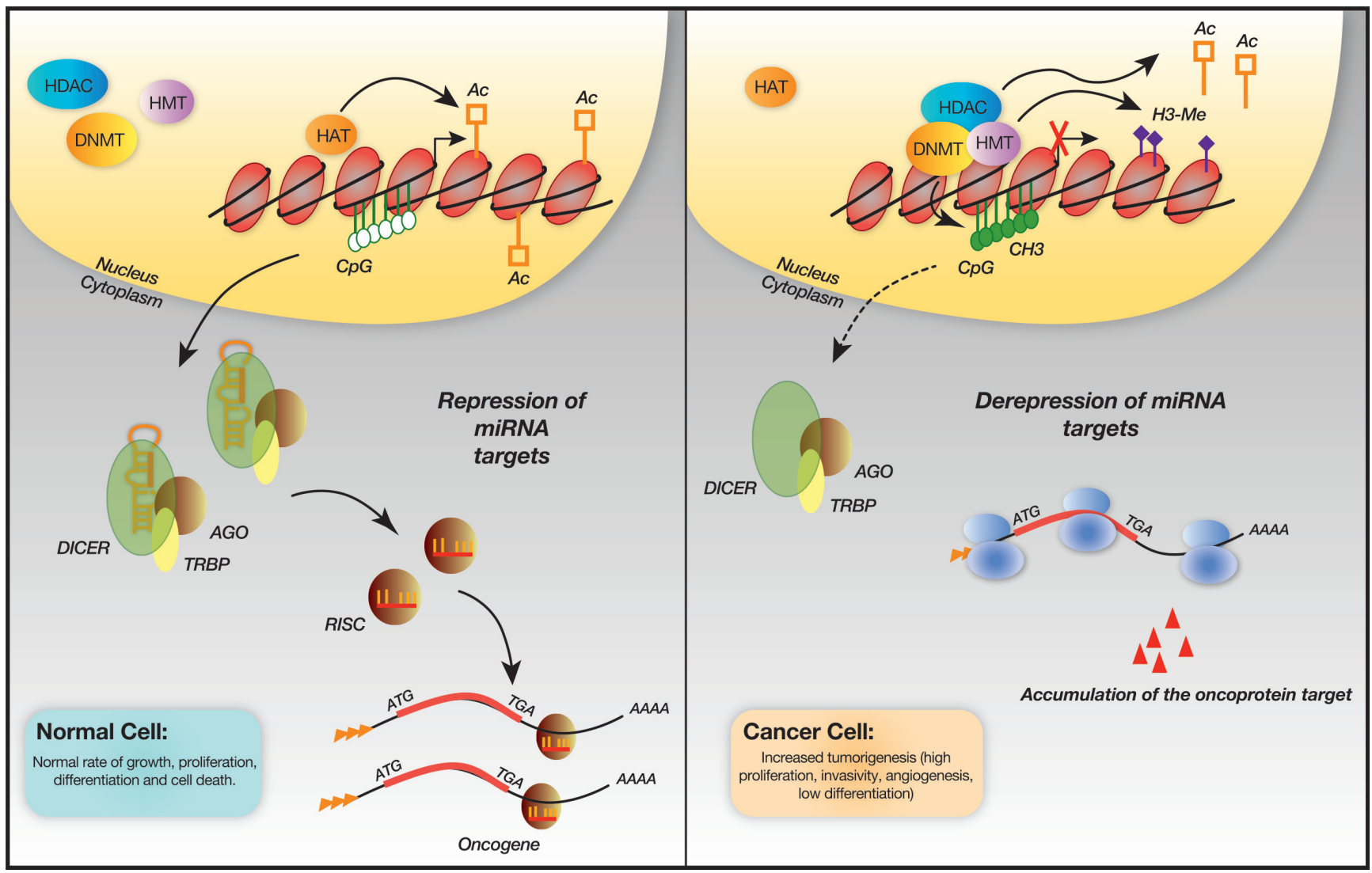

Figure 1. Epigenetic control of miRNA expression

The down-regulation of miRNAs that function as tumor suppressors could lead to tumor formation and aggressive phenotypes through the loss of the translational repression of several oncoproteins. The effect of epigenetic silencing may be mediated by methylation and loss of acetylation on the miRNA gene. The gain of repressive histone marks, such as histone trimethylation could prevent the transcriptional activation of miRNA genes. Abbreviations: CH3, methyl-cytosine; HMT, histone methyl-transferase; HDAC, histone deacetylase; DNMT, DNA methyl-transferase; HAT, histone acetyl-transferase; CpG, CpG islands; Ac, acetyl group; H3-Me, trimethylation of the histone H3 at the K4 residue; ATG, translation start codon; TGA, translation stop codon. Adapted from [69] with a permission of Elsevier (License number 3557660139817). 
cancer in developed countries [3]. A heterogeneous nature of endometrial cancer is observable to a lesser extent than in ovarian cancer. In addition to a traditional classification of the two major groups, type I endometrioid and type II serous tumors, the ongoing novel molecular classifications have been considered recently (see [12]).

Finding novel diagnostic, screening, treatment and monitoring opportunities for these cancers remains the great challenge of the current biomedical research. MicroRNAs have emerged recently as the key regulators of cellular processes functioning at post-transcriptional level and presenting potential dysregulations applicable in cancer diagnostics, monitoring and therapeutics [13, figs. 1 and 2]. For diagnostic purposes, circulating miRNAs (particularly in plasma/serum) have appeared as the most promising source of clinical material $[14,15]$. Several investigations proving that circulating miRNAs encompass a promising diagnostic potential also in gynaecological cancers have been published recently. Here, we reviewed the current knowledge on cell-free and whole blood microRNAs expression revealing their underestimated potential as perspective and promising diagnostic biomarkers in ovarian, endometrial and cervical cancers.

\section{Ovarian cancer}

Whole blood microRNA expression in ovarian cancer. There is only one study profiling microRNA expression in whole blood available for ovarian cancer [16]. This study evaluated whole blood-borne microRNA expression in microarray profiles from 24 post-menopausal patients with relapsed ovarian cancer (mostly of the serous type) and 15 age- and sex-matched healthy controls of unknown menopausal status. Among 147 significantly deregulated miRNAs, four miRNAs were still significantly different after Benjamini-Hochberg adjustment. While miR-30c1* has been shown up-regulated, three miRNAs (miR-342-3p, miR-181a* and miR-450b-5p) appeared down-regulated in ovarian cancer patients. Within this investigation, miR-30c- $1^{\star}, \mathrm{miR}-191$, miR-155, miR-16, miR-106b, miR-146a, miR-29a and miR-383 previously found to be de-regulated in ovarian cancer have been shown up- or down-regulated similarly as in previous investigations [16] (see Table 1).

Serum/plasma microRNA expression in ovarian cancer. The first pioneer study focused on exosome microRNAs in

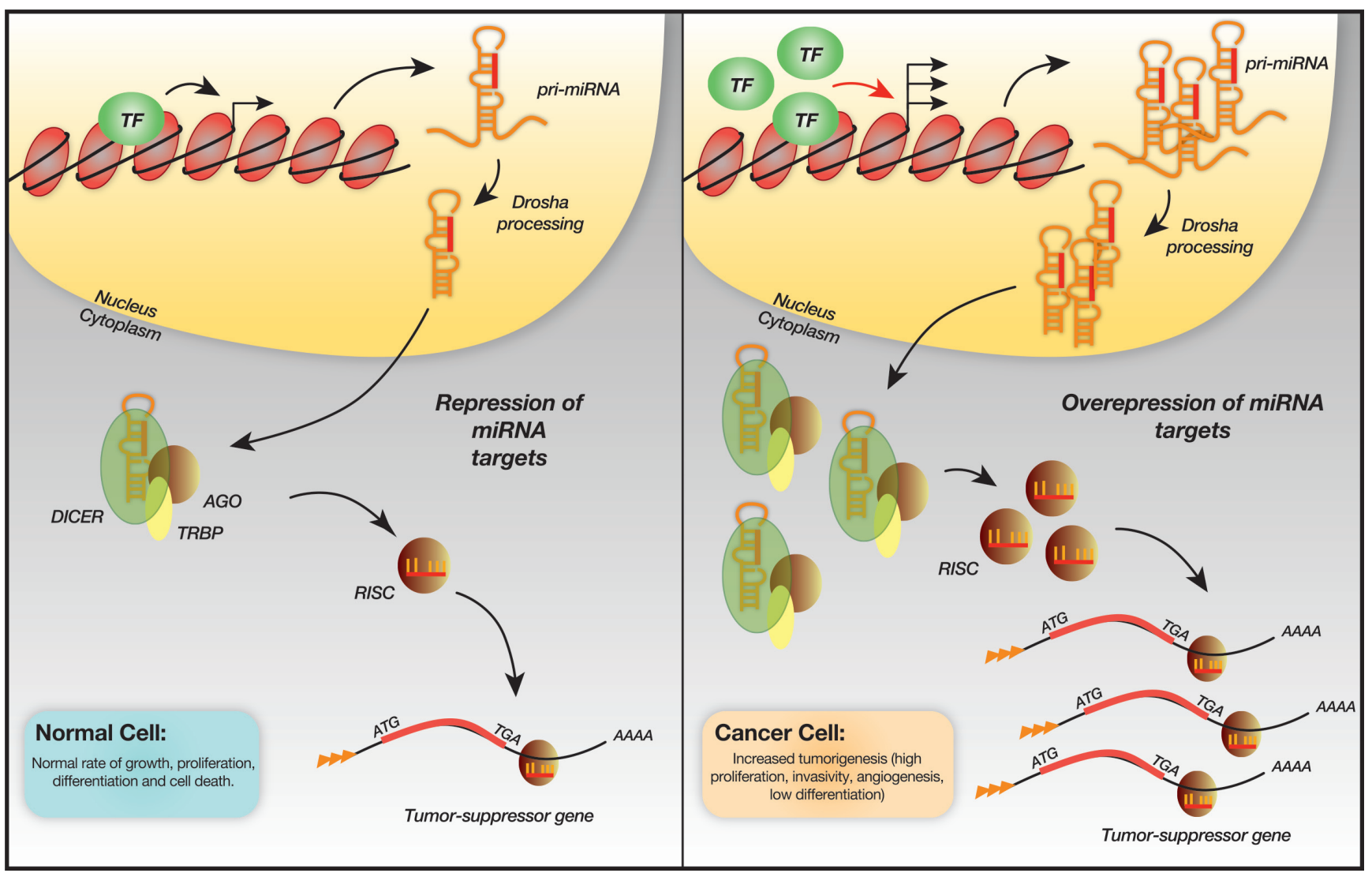

Figure 2. Transcriptional control of miRNA expression

The overexpression of miRNAs might induce tumor formation through the repression of several tumor suppressor genes. The overexpression and/or activation of a transcription factor at inappropriate times or in the wrong tissues could explain the increased level of miRNAs.

Abbreviations: TF, transcription factor; ATG, translation start codon; TGA, translation stop codon. Adapted from [69] with a permission of Elsevier (License number 3557660139817 ). 
Table 1. List of de-regulated microRNAs found in ovarian, endometrial and cervical carcinomas in blood, plasma/serum and urine samples

\begin{tabular}{|c|c|c|c|c|c|c|}
\hline Type of cancer & Detailed specification & $\begin{array}{l}\text { Up-regulated } \\
\text { microRNAs }\end{array}$ & $\begin{array}{l}\text { Down-regulated } \\
\text { microRNAs }\end{array}$ & Sample source & Methodology & Reference \\
\hline $\begin{array}{l}\text { Ovarian } \\
\text { carcinoma }\end{array}$ & $\begin{array}{l}\text { Relapsed ovarian } \\
\text { cancer: serous }(n=22) \text {, } \\
\text { endometrioid }(n=2) \\
\text { Control samples }(n=15) \text {. }\end{array}$ & $\begin{array}{l}\text { miR-16, miR-30c-1*, } \\
\text { miR-187, miR-191, } \\
\text { miR-383, miR-423-3p, } \\
\text { miR-499-3p, miR-574-5p, } \\
\text { miR-1181, miR-1228, } \\
\text { miR-1253, miR-1254, } \\
\text { miR-1289, miR-1908, } \\
\text { miR-1915 }\end{array}$ & $\begin{array}{l}\text { miR-28-3p, miR-29a, } \\
\text { miR-106b, miR-138-2*, } \\
\text { miR-146a, miR-155, } \\
\text { miR-181a*, miR-181a-2*, } \\
\text { miR-192, miR-342-3p, } \\
\text { miR-450-5p, miR-616*, } \\
\text { miR-628-5p, miR-1287, } \\
\text { let-7f-1* }\end{array}$ & Whole blood & $\begin{array}{l}\text { Geniom Biochip } \\
\text { miRNA homo } \\
\text { sapiens array. }\end{array}$ & {$[16]$} \\
\hline $\begin{array}{l}\text { Ovarian } \\
\text { carcinoma }\end{array}$ & $\begin{array}{l}\text { Serous carcinomas }(\mathrm{n}= \\
50), \text { benign samples }(\mathrm{n}= \\
10), \text { control samples }(\mathrm{n} \\
=10)\end{array}$ & $\begin{array}{l}\text { miR-21, miR-141, miR- } \\
\text { 200a, miR-200b, miR- } \\
\text { 200c, miR-203, miR-205, } \\
\text { miR-214 }\end{array}$ & & $\begin{array}{l}\text { EpCAM-positive } \\
\text { tumor exosomes in } \\
\text { blood }\end{array}$ & $\begin{array}{l}\text { Ocean Ridge } \\
\text { Biosciences } \\
\text { microarrays, } \\
\text { GenePix 4000A }\end{array}$ & {$[17]$} \\
\hline $\begin{array}{l}\text { Ovarian } \\
\text { carcinoma }\end{array}$ & $\begin{array}{l}\text { EOC }(\mathrm{n}=28), \text { serous } \\
(60 \%) \text {, clear cell }(21.2 \%) \text {, } \\
\text { endometrioid }(12 \%) \text {, } \\
\text { mucinous }(6 \%) . \text { Control } \\
\text { samples }(\mathrm{n}=15) .\end{array}$ & $\begin{array}{l}\text { miR-21, miR-29a, miR- } \\
\text { 92, miR-93, miR-126 }\end{array}$ & $\begin{array}{l}\text { miR-99b, miR-127, miR- } \\
155\end{array}$ & Blood serum & $\begin{array}{l}\text { TaqMan Array } \\
\text { Human MicroRNA } \\
\text { Panel, single } \\
\text { tube TaqMan } \\
\text { MicroRNA Assays } \\
\end{array}$ & {$[20]$} \\
\hline $\begin{array}{l}\text { Ovarian } \\
\text { carcinoma }\end{array}$ & $\begin{array}{l}\text { Serous carcinomas }(n \\
=68), \text { others }(n=26) \\
\text { Control samples }(n=40)\end{array}$ & $\operatorname{miR}-21$ & $\mathrm{n} / \mathrm{a}$ & Blood serum & $\begin{array}{l}\text { TaqMan } \\
\text { microRNA assay }\end{array}$ & {$[23]$} \\
\hline $\begin{array}{l}\text { Ovarian } \\
\text { carcinoma }\end{array}$ & $\begin{array}{l}\text { EOC samples (non- } \\
\text { specified) }(\mathrm{n}=50) \\
\text { Control samples }(\mathrm{n}=50)\end{array}$ & $\operatorname{miR}-92$ & & Blood serum & $\begin{array}{l}\text { SYBR green qRT- } \\
\text { PCR }\end{array}$ & {$[24]$} \\
\hline $\begin{array}{l}\text { Ovarian } \\
\text { carcinoma }\end{array}$ & $\begin{array}{l}\text { Total EOC cases }(\mathrm{n}=360) \text {, } \\
\text { incl. } 179 \text { serous tumors } \\
(49.7 \%), 86 \text { endometrioid } \\
\text { tumors }(23.9 \%), 33 \\
\text { mucinous tumors }(9.2 \%), \\
15 \text { clear cell tumors } \\
(4.2 \%) \text {, and } 47 \\
\text { adenocarcinomas, Not } \\
\text { Otherwise Specified (NOS) } \\
(13.0 \%) \text {. } \\
\text { Control samples }(\mathrm{n}=200) \text {. }\end{array}$ & miR-205 & let-7f & Blood plasma & $\begin{array}{l}\text { TaqMan } \\
\text { Array (TLDA) }\end{array}$ & {$[25]$} \\
\hline $\begin{array}{l}\text { Ovarian } \\
\text { carcinoma }\end{array}$ & $\begin{array}{l}\text { Serous carcinomas }(\mathrm{n}= \\
18), \text { control samples }(\mathrm{n} \\
=12)\end{array}$ & & $\begin{array}{l}\text { miR-132, miR-26a, } \\
\text { let-7b, miR-145, and } \\
\text { miR-143 }\end{array}$ & $\begin{array}{l}\text { Blood serum } \\
\text { (filtration through } \\
\text { a } 0.2 \mu \mathrm{m} \text { filter) }\end{array}$ & $\begin{array}{l}\text { Microarray } \\
\text { Affymetrix } \\
\text { miRNAV2.0. } \\
\text { TaqMan qRT-PCR. }\end{array}$ & {$[26]$} \\
\hline $\begin{array}{l}\text { Ovarian } \\
\text { carcinoma }\end{array}$ & $\begin{array}{l}\text { Ovarian carcinomas (type } \\
\text { unspecified) }(n=31) \\
\text { benign samples }(n=23) \\
\text { Control samples }(n=8) .\end{array}$ & miR-22 and miR-93 & miR-106b & Blood serum & $\begin{array}{l}\text { SYBR green qRT- } \\
\text { PCR }\end{array}$ & {$[28]$} \\
\hline $\begin{array}{l}\text { Ovarian } \\
\text { carcinoma }\end{array}$ & $\begin{array}{l}\text { Serous carcinomas }(\mathrm{n}= \\
42), \text { benign samples }(\mathrm{n}= \\
\text { 36). Control samples }(\mathrm{n} \\
=23)\end{array}$ & $\begin{array}{l}\text { miR-1274a, miR-625-3p, } \\
\text { and miR-720 }\end{array}$ & $\begin{array}{l}\text { miR-106a, miR-126, miR- } \\
\text { 146a, miR-150, miR-16, } \\
\text { miR-17, miR-19b, miR- } \\
\text { 20a, miR-223, miR-24, } \\
\text { and miR-92a, miR-106b, } \\
\text { miR-191, miR-193a-5p, } \\
\text { miR-30b, miR-30a-5p, } \\
\text { miR-30c, miR-320, and } \\
\text { miR-328 }\end{array}$ & $\begin{array}{l}\text { Blood plasma } \\
\text { (ultracentrifugation, } \\
\text { plasma without } \\
\text { exosomes) }\end{array}$ & $\begin{array}{l}\text { Taqman Open } \\
\text { Array MicroRNA }\end{array}$ & {$[29]$} \\
\hline $\begin{array}{l}\text { Ovarian } \\
\text { carcinoma }\end{array}$ & $\begin{array}{l}\text { Serous carcinomas }(\mathrm{n} \\
=28) . \text { Control samples }(\mathrm{n} \\
=28) .\end{array}$ & $\begin{array}{l}\text { miR-200a, miR-200b and } \\
\text { miR-200c }\end{array}$ & & Blood serum & $\begin{array}{l}\text { Exiqon MiRCURY } \\
\text { Locked Nucleic } \\
\text { Acid Arrays }\end{array}$ & {$[30]$} \\
\hline $\begin{array}{l}\text { Ovarian } \\
\text { carcinoma }\end{array}$ & $\begin{array}{l}\text { EOC, serous carcinomas }(n \\
=5) \text {, others }(n=4), \text { benign } \\
\text { ovarian samples }(n=3) . \\
\text { Control samples }(n=13) .\end{array}$ & miR-92a & miR-106b & Urine & $\begin{array}{l}\text { Taqman } \\
\text { microRNA real } \\
\text { time PCR }\end{array}$ & {$[34]$} \\
\hline
\end{tabular}


Table 1. (continued)

\begin{tabular}{|c|c|c|c|c|c|c|}
\hline Type of cancer & Detailed specification & $\begin{array}{l}\text { Up-regulated } \\
\text { microRNAs }\end{array}$ & $\begin{array}{l}\text { Down-regulated } \\
\text { microRNAs }\end{array}$ & Sample source & Methodology & Reference \\
\hline $\begin{array}{l}\text { Endometrial } \\
\text { carcinoma }\end{array}$ & $\begin{array}{l}\text { Endometrioid } \\
\text { endometrial cancers ( } \mathrm{n} \\
=48 \text { ), control samples ( } \mathrm{n} \\
=14 \text { ) }\end{array}$ & $\begin{array}{l}\text { miR-99a, miR-100 and } \\
\text { miR-199b }\end{array}$ & & Blood plasma & $\begin{array}{l}\text { ViiA7 Real-Time } \\
\text { PCR System }\end{array}$ & {$[31]$} \\
\hline $\begin{array}{l}\text { Endometrial } \\
\text { carcinoma }\end{array}$ & $\begin{array}{l}\text { Endometrioid endometrial } \\
\text { cancers }(\mathrm{n}=34) \text {. Control } \\
\text { samples }(\mathrm{n}=14) \text {. }\end{array}$ & $\begin{array}{l}\text { miR-92a, miR-141, miR- } \\
\text { 200a, miR-203, miR-449a, } \\
\text { miR-1228 and miR-1290 }\end{array}$ & miR-9 and miR-301b & Blood plasma & $\begin{array}{l}\text { ViiA7 Real-Time } \\
\text { PCR System }\end{array}$ & [32] \\
\hline $\begin{array}{l}\text { Endometrial } \\
\text { carcinoma }\end{array}$ & $\begin{array}{l}\text { Endometrioid } \\
\text { endometrial cancers ( } n= \\
\text { 33). Control samples ( } n \\
=42 \text { ). }\end{array}$ & $\begin{array}{l}\text { miR-222, miR-223, miR- } \\
186 \text { and miR-204 }\end{array}$ & & Blood serum & $\begin{array}{l}\text { TaqMan array } \\
\text { human microRNA } \\
\text { A+B cards set v3.0 } \\
\text { real time PCR }\end{array}$ & [33] \\
\hline $\begin{array}{l}\text { Endometrial } \\
\text { carcinoma }\end{array}$ & $\begin{array}{l}\text { Endometrioid endometrial } \\
\text { cancers }(\mathrm{n}=9) \text {, benign } \\
\text { endometrial samples ( } \mathrm{n} \\
=3 \text { ). Control samples ( } \\
=13) \text {. }\end{array}$ & & miR-106b & Urine & $\begin{array}{l}\text { Taqman } \\
\text { microRNA real } \\
\text { time PCR }\end{array}$ & {$[34]$} \\
\hline $\begin{array}{l}\text { Cervical } \\
\text { carcinoma }\end{array}$ & $\begin{array}{l}\text { Squamous cell cervical } \\
\text { cancers }(\mathrm{n}=71) \text {, cervical } \\
\text { adenocarcinoma }(\mathrm{n}=19) \text {. } \\
\text { Control samples }(\mathrm{n}=50)\end{array}$ & & miR-218 & Blood serum & $\begin{array}{l}\text { Taqman } \\
\text { microRNA real } \\
\text { time PCR }\end{array}$ & {$[35]$} \\
\hline $\begin{array}{l}\text { Cervical } \\
\text { carcinoma }\end{array}$ & $\begin{array}{l}\text { Cervical squamous cell } \\
\text { carcinomas }(n=80) \\
\text { Control samples }(n=20)\end{array}$ & $\begin{array}{l}\text { miR-1246, miR-20a, miR- } \\
\text { 2392, miR-3147, miR- } \\
\text { 3162-5p and miR-4484 }\end{array}$ & & Blood serum & $\begin{array}{l}\text { Human microRNA } \\
\text { OneArray, SYBR } \\
\text { Green real time } \\
\text { PCR }\end{array}$ & [36] \\
\hline $\begin{array}{l}\text { Cervical } \\
\text { carcinoma }\end{array}$ & $\begin{array}{l}\text { Cervical squamous cell } \\
\text { carcinoma }(n=80) \\
\text { Control samples }(n=20)\end{array}$ & miR-20a, miR-203 & & Blood serum & $\begin{array}{l}\text { SYBR Green PCR } \\
\text { kit, BIO-chromo4 } \\
\text { (Bio-Rad) Real- } \\
\text { Time PCR System }\end{array}$ & [37] \\
\hline
\end{tabular}

serum of ovarian cancer patients has been published in 2008 [17]. The study showed a correlation of microRNA expression between tumor tissues and the tumor-released EpCAM-positive exosomes while failing to find their expression in control samples. Following these studies, further investigations were focused on exosome microRNAs isolated by different means in many other cancer types (e.g. $[18,19])$. Going back to ovarian cancer, Resnick et al. [20] analysed microRNA expression in serum of ovarian cancer patients. They found miRNAs-21, 92, 93, 126 and 29a significantly over-expressed, and miRNAs-155, 127 and 99b significantly under-expressed when comparing sera of cancer and control patients.

In concordance with the oncogenic status and the over-expression of miR-21 found previously in ovarian cancer tissues (e.g. $[21,22])$, serum levels of this miRNA were investigated [23]. Here, Xu et al. [23] found higher levels of miR-21 in ovarian cancer patients sera associated also with advanced FIGO stage, high tumor grade, and shortened overall survival.

It has been shown recently that miR-92 may be found upregulated in serum of ovarian cancer patients [24]. Within this study, 50 ovarian cancer patients and 50 controls were enrolled, and miR-16 was used as an endogenous control. Up-regulation of miR-92a was associated with regional lymph node involvement and advanced clinical stages (III-IV) [24]. The large recent study [25] investigated microRNA expression in plasma samples of ovarian cancer patients (360 EOC patients, 200 healthy controls). The study revealed higher levels of miR-205 and lower let-7f expression in cancer samples than in controls, the lower expression of let- $7 \mathrm{f}$ was also associated with a poor prognosis in EOC patients. In comparison of early and advanced stages, miR-483-5p expression was elevated in stages III and IV [25]. Down-regulation of microRNA expression in serum of ovarian cancer patients (18 serous cancers, 12 controls) was shown most markedly and significantly in miR-132, miR-26a, let-7b, miR-145, and miR-143 in the study of Chung et al. [26]. Distinct microRNA signatures in plasma samples of patients with endometriosis, endometriosis-associated ovarian cancer (EAOC) and healthy controls were revealed in another research [27]. Interestingly, both microRNAs associated with endometriosis and EAOC, respectively, found to be de-regulated significantly in comparison with healthy controls, were shown up-regulated (miR-21, miR-191, miR-16, miR15b, miR-1977, miR-1979, miR-1973, miR-1974, miR-4284, and miR-195) [27].

The very recent study [28] applied a combined approach using the deep sequencing technology (Solexa) and real-time 
PCR for microRNA analysis of serum in ovarian cancer. This study involving 31 patients with ovarian carcinomas, 23 patients with benign ovarian tumors, and 8 control samples confirmed the differential expression of four microRNAs. Here, miR-22 and miR-93 were shown to be consistently (> 2 -fold) up-regulated and miR-451 up-regulated in cancer sera. On the other hand, miR-106b appeared significantly down-regulated in cancer samples [28]. Another search for finding relevant diagnostic serum circulating microRNAs has been published recently [29]. There were 42 serous epithelial cancer samples, 36 benign samples and 23 control samples of patients enrolled within this investigation. The downregulated expression (at least 10-fold) in cancer samples compared to control samples was found in miR-106a, miR126, miR-146a, miR-150, miR-16, miR-17, miR-19b, miR-20a, miR-223, miR-24, and miR-92a. The down-regulated expression was also observed in miR-106b, miR-191, miR-193a-5p, miR-30b, miR-30a- 5p, miR-30c, miR-320, and miR-328. Three miRNAs, miR-1274a, miR-625-3p, and miR-720 were up-regulated in cancer samples, but they were shown not to be good discriminators between cancer and control samples [29]. In another study, three serum miRNAs (miR-200a, miR$200 \mathrm{~b}$ and miR-200c) appeared to be up-regulated significantly in serous ovarian carcinomas $(n=28)$, with a multivariate combination of miR- $200 \mathrm{~b}+\mathrm{c}$ resulting in $\mathrm{AUC}=0.784$ within ROC-AUC analysis [30].

When comparing the above-mentioned studies, consistent results could be considered particularly for onco-miR- 21 . The miR-21 has been found to be up-regulated across several studies $[20,23,27]$. Controversial results can be seen in miR-92a, shown mostly to be up-regulated [20,24], but down-regulated elsewhere in cancer-related samples [29].

For details on serum/plasma microRNA expression in ovarian cancer see Table 1.

\section{Endometrial cancer}

Serum/plasma microRNA expression in endometrial cancer. Torres et al. published the first study focused on microRNA expression both in tissue and plasma samples of patients with endometrial cancer [31]. They investigated expression of miR-99a, miR-100 and miR-199b, three miRNAs targeting mTOR kinase. The up-regulated expression of mTOR kinase in EEC tissues was associated with a decreased expression of the three investigated miRNAs in these samples. However, the expression of these miRNAs in plasma was found increased in comparison with control samples. A combined signature for plasma miRNAs (miR-99a/miR-199b) resulted in $88 \%$ sensitivity and $93 \%$ specificity, indicating a good diagnostic potential. Sixteen miRNAs were chosen for the expression analysis using plasma of 34 EEC patients and 14 controls in another recent study [32]. Two miRNAs were found down-regulated (miR-9 and miR-301b), and seven miRNAs up-regulated (miR-92a, miR-141, miR-200a, miR-203, miR-449a, miR-1228 and miR-1290) in EEC plasma samples. Using logistic regression, the miR-9/miR-1228 and miR-9/miR-92a signatures appeared as good classifiers (AUC values $\sim 0.9$ ) [32].

The first, genome-wide serum miRNA expression profiling analysis of 754 microRNAs using TLDA technology and follow-up analyses, has been published recently [33]. This study identified four serum miRNAs (miR-222, miR-223, miR-186 and miR-204) to be up-regulated significantly in the endometrial cancer patients $(\mathrm{n}=26)$ in comparison with the control samples $(\mathrm{n}=22)$. The four-miRNA signature resulted in an AUC of 0.927 ((95\% CI, 0.845-1.000) [33].

For details on serum/plasma microRNA expression in endometrial cancer see Table 1.

MicroRNA expression in urine of ovarian and endometrial cancers. Our pilot study to explore cell-free urinary microRNAs in ovarian and endometrial cancers has revealed a feasibility of assessing de-regulated miRNAs expression in urine of these gynaecological cancer patients for the first time [34]. We performed a set of several experiments, analysing two supernatant fractions and exosome RNA fraction. Presurgery and post-surgery ovarian cancer samples showed no significant differences between these two sampling modalities. Within the expression of candidate individual cell-free miRNAs coming from supernatant fractions, several differentially expressed miRNAs were identified. In ovarian cancer, miR92a was found up-regulated, and miR-106b down-regulated, the latter miRNAs were revealed as down-regulated also in endometrial cancer (Table 1). Interestingly, we could not find any miRNA de-regulated using exosomal RNA both in ovarian and endometrial cancers. This pilot study identified the potential of assessment of urine microRNA expression as novel diagnostic tool for non-urinary tract-related diseases such as ovarian and endometrial cancers [34]. However, further validation studies investigating more samples and more miRNAs are needed.

\section{Cervical cancer}

Serum/plasma microRNA expression in cervical cancer. The recent attention of investigators has been concentrated also on serum microRNAs in cervical cancer. In 2012, the first report on serum microRNA in cervical cancer (cervical adenocarcinoma and squamous cell cancer) has been published [35]. A down-regulated expression of serum miR-218 as the only one microRNA investigated was shown in cancer patients, also with associations with cervical adenocarcinoma, later stages and lymph node metastasis. U6 was used as the endogenous control [35].

Later on, two further reports have followed. Chen et al. [36] profiled 89 microRNAs in tissue and serum of cervical cancer patients ( 80 cervical SCC patients, 20 control patients involved). Several of them (miR-1246, miR-20a, miR-2392, miR-3147, miR-3162-5p and miR-4484) were found upregulated both in tissue and serum samples. These miRNAs were also able to predict lymph node metastasis with good 
sensitivity and specificity [36]. Zhao et al. [37] showed the up-regulated expression of miR-20a and miR-203 in serum of patients with cervical squamous cell carcinomas compared with control patients. They found also the association of lymph node metastasis with the over-expressed miR-20a [37]. For details on serum/plasma microRNA expression in cervical cancer see Table 1 .

Stability of extracellular microRNA and the sources of microRNAs in cell-free samples. Initially, the presence of RNases in blood hindered the investigations assuming that RNA should not be present in the body fluids rich in ribonucleases such as serum, or considered as being a result of cell death and lyses [38]. However, the reports on RNA detection in plasma of nasopharyngeal carcinoma patients [39] and serum of malignant melanoma patients [40] showed that RNA may be readily de- tected in these biological fluids. In 2008, three ground-breaking studies of Lawrie et al. [41], Mitchel et al. [42] and Chen et al. [43] proving the remarkable stability of endogenous extracellular microRNAs and differences between cancer and control patients were published. Moreover, microRNAs in serum were shown to be highly stable in the harsh conditions (extreme temperature and $\mathrm{pH}$ ) and even more resistant to RNase digestion than tissue or cellular microRNAs [43]. However, the exact origin and the mechanisms stabilizing the circulating miRNAs could not be addressed at that time.

Following reports revealed the presence of extracellular miRNAs in diverse body fluids such as urine, saliva, breast milk, seminal plasma, tears, amniotic fluid, colostrum, bronchial lavage, cerebrospinal fluid, peritoneal fluid, and pleural fluid [44-46].
Vesicles-free miRNA

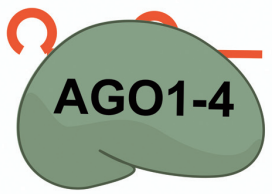

$\left.\begin{array}{l}\text { Extracellular } \\ \text { space }\end{array}\right\} \begin{aligned} & \text { Release after cell death } \\ & \text { Specific secretion? }\end{aligned}$

\section{Apoptotic body-enclosed miRNA}

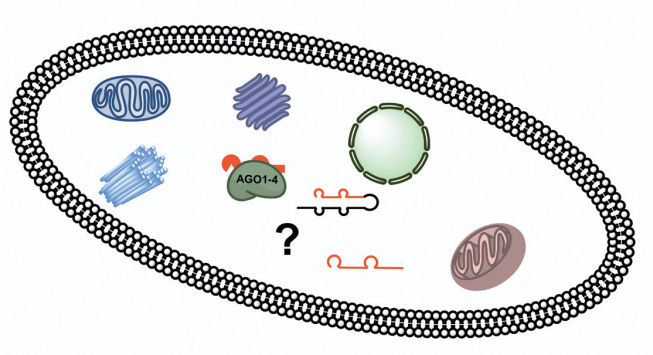

\section{Shedding vesicles and exosomes packaged} miRNA

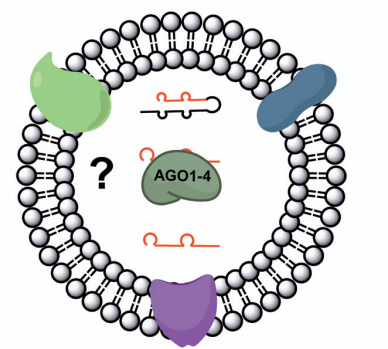

HDL-associated miRNA

Specific secretion? Passive secretion

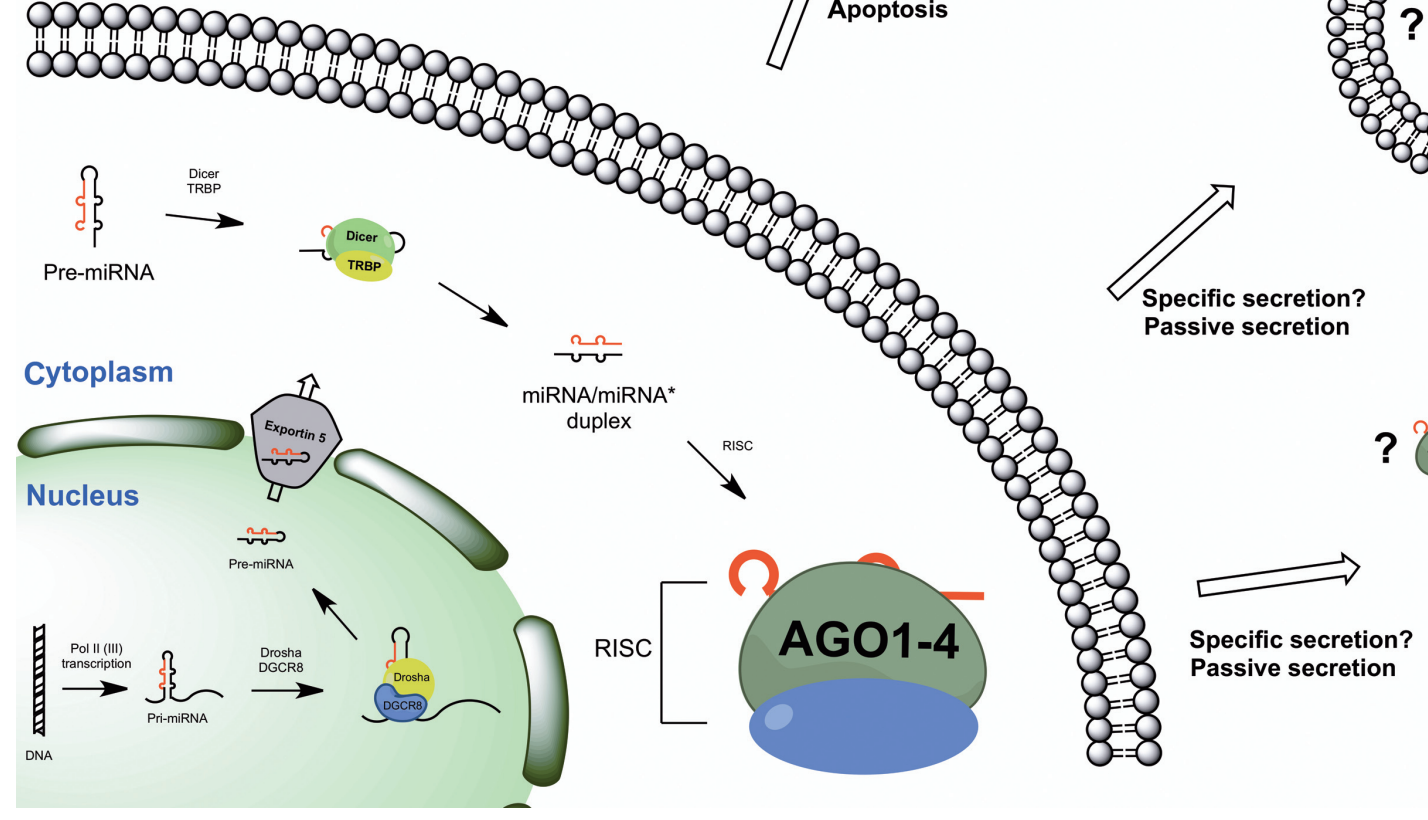
Apoptosis

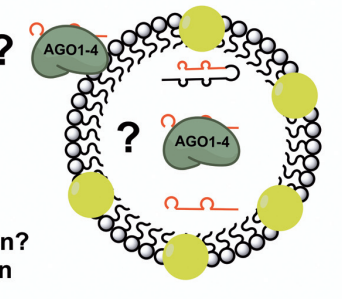

Figure 3. Origin of intracellular and extracellular miRNAs

The mature miRNA strand eventually serves as the guide for RISC-mediated mRNA targeting resulting in either mRNA cleavage or translational interference. The three types of membranous vesicles that contain extracellular miRNA are apoptotic bodies, shedding vesicles, and exosomes. Besides these, extracellular miRNA can also be vesicle free and associated with either AGO proteins alone or be incorporated into HDL particles. Adapted from [49] with permission of Elsevier (License number 3561921092056 ). 
The stability of circulating microRNAs was then attributed to their carriers, i.e. various kinds of the microvesicles (microparticles, exosomes, and other vesicular structures) providing the protection of trapped miRNAs against digestion by RNases while naked miRNAs appeared to be RNase-sensitive [42]. These vesicular structures mediating intercellular interactions and communications by transporting bioactive molecules (microRNAs, mRNA, proteins, and lipids) between cells have been then subjected to further intensive experimental investigations. However, it became evident that the extracellular miRNAs are a heterogeneous entity consisting of various fractions. Interestingly, microvesicle-associated miRNAs appeared as the least represented fraction while AGO-protein-bound form represented $90-95 \%$ of cell-debris-free plasma miRNAs $[47,48]$. Two major theories suggested recently consider extracellular miRNAs as 1) "by-products" of cellular activity and cell death, and/or 2) on-purpose released cell-cell signalling messengers [49]. The possible mechanisms of miRNA secretion include packaging into various forms of apoptotic bodies, shedding microvesicles, exosomes and lipoprotein HDL particles or binding with associated AGO proteins (Fig. 3 , [49]). The exact functions of extracellular miRNAs remain to be further elucidated [49].

Meanwhile, many studies explored the potential of body fluids-associated cell-free microRNAs for the diagnostic purposes, particularly using patients' serum/plasma. Results of the investigations for gynaecological cancers are presented above. It should be noted that diagnostically-focused studies have not usually explored the miRNAs sources in detail. There exists growing evidence that microRNA expression in blood samples such as serum/plasma may be associated with the blood components, including leukocytes, erythrocytes and thrombocytes. However, in pathological states including cancer, other relevant sources such as tumor cells, and other tissue- and organ-specific cells may release miRNAs into a blood circulation and thus may contribute to the global miRNAs expression. It may be further affected by genetic and epigenetic alterations and externally by other expression modulators such as smoking, food or treatment [50-53]. However, external miRNAs have not been proved yet convincingly to be a functioning part of human miRNome, and alterations in miRNA expressions are suspected to be due to the endogenously originated miRNAs [54].

Blood is a complex body fluid composed particularly of blood cells (erythrocytes, leukocytes and thrombocytes) and plasma. It has been shown in healthy subjects that microRNA expression profile in serum was shared between blood cells (all cellular components of blood here were considered as blood cells) and serum [43]. In the same paper, however, the remarkably different miRNA expression pattern between blood cells and serum was demonstrated in lung cancer patients. Differential serum miRNA expression of lung cancer patients and colorectal patients in comparison with healthy subjects has been shown as well [43]. The "tumor-related" miRNAs common in both cancer types were identified and the authors suggested them to be in a relation with the body's immune system and a general inflammatory response. Authors further concluded that serum microRNA in cancer may reflect both blood cells and other tissues affected by ongoing diseases as well [43].

It has been demonstrated experimentally using mice xenograft models that plasma microRNAs may represent tumor-derived miRNAs reaching the circulation [42]. Also other investigations proved the impact of tumor-released cells on the plasma/serum microRNA expression, implicating that it may reflect both the microRNAs released by blood and tumor cells. Taylor et al. [17] focused on ovarian cancer exosomes, and found that microRNAs expressions of the EpCAM positive exosomes circulating in the blood were broadly consistent with the ovarian tumor cells of the same patients. Among 218 detected miRNAs, 175 miRNAs (i.e. 80\%) were not significantly different between the ovarian tumor cells and their corresponding exosomes, 12 were up-regulated in cells, and 31 were found with increased expression in exosomes. The study corroborated that cancer-specific signatures based on microRNA expression are shared both in cellular (tumor) and exosome (plasma) compartments of ovarian cancer patients [17].

Evidently, many miRNAs reported as the tumor markers may be found expressed abundantly in the blood plasma. Blood cells have been shown to substantially affect plasma microRNAs expression. Pritchard et al. [55] demonstrated that $58 \%$ of the 79 miRNAs reported as cancer biomarkers may be found highly expressed in one or more blood cell types. In more detail, ten miRNAs were then investigated to test the potential correlations of the miRNA expression and blood cell counts. Myeloid-expressed miRNAs (let-7a, miR-223, miR-197, and miR-574-3p) were positively correlated with the myeloid blood cell counts (neutrophils and platelets), and the lymphoid-enriched miR-150 was correlated with lymphocyte counts [55].

However, many tissue-specific miRNAs exist in blood circulation although they cannot be derived from blood cells [56-59]. It can be assumed that among over 2,000 human miRNAs currently known, some plasma miRNAs may be clearly associated with a particular disease. For example, in gastric cancer, miR-191 was found up-regulated both in tissue and serum, and the inhibition of this oncogenic miRNA resulted in reduced cell proliferation, cell cycle progression, and impaired cell migration and invasion in HGC-27 cell line [60].

In a contradiction with previous thoughts considering the mature erythrocytes as lacking the microRNAs, Chen et al. [61] proved that both reticulocytes and erythrocytes may contain microRNAs. Moreover, their expression in the mature erythrocytes differed from that of the reticulocytes and leukocytes, and it was suggested that erythrocytes may be contributing to the majority of the microRNA expression in whole blood [61].

Soon after the suggestions on microRNA presence in platelets (i.e. thrombocytes), the third type of anucleate blood cells, 
have emerged $[62,63]$, their occurrence has been evaluated elsewhere [64]. Further reports followed confirming the previous studies, and recently it has been shown that the platelets should be considered as the specific source of circulating miRNAs [65]. The levels of miR-24, miR-197, miR-191, and miR-223 identified to be abundant in platelets were increased in serum in comparison with platelet-poor plasma. Moreover, several miRNAs have been found to be affected and responsive to the anti-platelet therapy.

Lymphocytes have attracted attention of microRNA investigations due to their key role in host immune system for many years. As there exist many functional subpopulations of $\mathrm{T}$ cells, their microRNA expression diverges between them [66]. Moreover, different miRNAs have been implicated in the differentiation of both T cells and B cells [67]. Interestingly, corresponding miRNA de-regulations may be found in different sample sources including immune cells. For example, in multiple sclerosis there were several miRNAs up-regulated in both peripheral blood mononuclear cells (PBMCs) and brain white matter lesions, and also miRNAs simultaneously up-regulated in regulatory T cells (Tregs), plasma, blood cells, PBMCs and brain white matter tissues [68].

\section{Pitfalls and challenges of the current research}

It has become evident that many obstacles yet prevent introducing cell-free miRNAs as novel clinical diagnostics. As we have shown above, there is a limited number of studies investigating this type of samples in gynaecological malignancies. The studies may suffer from insufficient number of samples, application of different methods for miRNAs detection and various approaches for normalization of expression data. Possible complications may also arise from inadequate use of control samples, ethnogeographical issues, underestimated biological variation, and a complex origin of cell-free miRNAs occurring in blood/serum/plasma, or urine samples. More research will be needed to elucidate also the factors affecting the miRNAs expression at the epigenetic and transcriptional control levels known for cellular processes of miRNA functioning (see Figs. 1 and 2, [69]).

Despite these potential pitfalls, a much intensive focus on the diagnostically relevant samples should be encouraged. It is because the body fluids-based miRNA diagnostics are clinically more convenient, non-invasive strategies, giving the chance for an early diagnosis to be achieved with an implicated impact on patients' survival.

\section{Conclusions}

MicroRNAs are present and stable occurring not only in different tissues but also in various body fluids. Their resistance to digesting by RNases allows detecting and quantifying them in the sources easily available for diagnostic purposes, such as blood/plasma/serum and urine. Plasma/serum as the prominent representatives of investigated body fluids represent the heterogeneous population of various kinds of extracellular miRNAs of different origin. Blood cells, tumor cells and other organ/tissue-specific cells may serve as their major sources. Urine miRNAs may reveal as the novel diagnostic tool also for other than urinary tract-related diseases. Many questions on exact origin and functions of extracellular miRNAs remain to be answered. However, mounting evidence suggests that their expression harbours significant diagnostic potential with a broad impact on introducing novel biomarkers for various diseases including gynaecological cancers into clinical practice.

Acknowledgements: The financial support from the Charles University Prague (project PRVOUK-P27/LF1/1) and from the Ministry of Health of the Czech Republic (project FNBr 65269705) is appreciated.

\section{References}

[1] HEINTZ APM, ODICINO F., MAISONNEUVE, P. QUINN MA, BENEDET JL et al. Carcinoma of the ovary. Int J Gynaecol Obstet 2006; 95: S161-S192.

[2] SIEGEL R, MA J, ZOU Z, JEMAL A. Cancer statistics, 2014. CA Cancer J Clin, 2014; 64: 9-29. http://dx.doi.org/10.3322/ caac. 21208

[3] JEMAL A, BRAY F, CENTER MM, FERLAY J, WARD E, FORMAN D. Global cancer statistics. CA Cancer J Clin 2011; 61: 69-90. http://dx.doi.org/10.3322/caac.20107

[4] ERICKSON BK, CONNER MG, LANDEN J. The role of the fallopian tube in the origin of ovarian cancer. Am J Obstet Gynecol 2013; 209: 409-414. http://dx.doi.org/10.1016/j. ajog.2013.04.019

[5] KURMAN RJ, SHIH IM. Molecular pathogenesis and extraovarian origin of epithelial ovarian cancer-Shifting the paradigm. Hum Pathol 2011; 42: 918-931. http://dx.doi. org/10.1016/j.humpath.2011.03.003

[6] KOSHIYAMA M, MATSUMURA N, KONISHI I. Recent concepts of ovarian carcinogenesis: Type I and type II. BioMed Res Int 2014; 2014: 934261. http://dx.doi. org/10.1155/2014/934261

[7] ZAVESKY L, JANCARKOVA N, KOHOUTOVA M. Ovarian cancer: Origin and factors involved in carcinogenesis with potential use in diagnosis, treatment and prognosis of the disease. Neoplasma 2011; 58: 457-468. http://dx.doi.org/10.4149/ neo $2011 \quad 06 \quad 457$

[8] HATINA J. The dynamics of cancer stem cells. Neoplasma 2012; 59 (6): 700-707. http://dx.doi.org/10.4149/neo 2012092

[9] ZEIMET AG, REIMER D, SOPPER S, BOESCH M, MARTOWICZ A et al. Ovarian cancer stem cells. Neoplasma 2012; 59: 747-755. http://dx.doi.org/10.4149/neo 2012 094

[10] TOUBOUL C, VIDAL F, PASQUIER J, LIS R, RAFII A. Role of mesenchymal cells in the natural history of ovarian cancer: A review Journal of Translational Medicine 2014; $12: 271$.

[11] BANNO K, IIDA M, YANOKURA M., KISU I, IWATA T et al. MicroRNA in cervical cancer: OncomiRs and tumor sup- 
pressor miRs in diagnosis and treatment. Sci World J 2014; 2014: 178075. http://dx.doi.org/10.1155/2014/178075

[12] MURALI R, SOSLOW RA, WEIGELT B. Classification of endometrial carcinoma: More than two types. Lancet Oncol, 2014; 15: e268-e278.

[13] IORIO M, CROCE C. MicroRNA dysregulation in cancer: diagnostics, monitoring and therapeutics. A comprehensive review. EMBO Mol Med 2012; 4: 143-159. http://dx.doi. org/10.1002/emmm.201100209

[14] ZEN K, ZHANG CY. Circulating MicroRNAs: A novel class of biomarkers to diagnose and monitor human cancers. Med Res Rev 2012; 32: 326-348. http://dx.doi.org/10.1002/ $\underline{\text { med.20215 }}$

[15] KOSAKA N, IGUCHI H, OCHIYA T. Circulating microRNA in body fluid: A new potential biomarker for cancer diagnosis and prognosis. Cancer Sci 2010; 101: 2087-2092. http://dx.doi. org/10.1111/j.1349-7006.2010.01650.x

[16] HAUSLER SFM, KELLER A, CHANDRAN PA, ZIEGLER K, ZIPP K et al. Whole blood-derived miRNA profiles as potential new tools for ovarian cancer screening. Br J Cancer 2010; 103(5): 693-700. http://dx.doi.org/10.1038/sj.bjc.6605833

[17] TAYLOR DD, GERCEL-TAYLOR C. Microrna signatures of tumor-derived exosomes as diagnostic biomarkers of ovarian cancer. Gynecol Oncol 2008; 110: 13-21. http://dx.doi. org/10.1016/j.ygyno.2008.04.033

[18] RABINOWITS G, GERCEL-TAYLOR C, DAY JM, TAYLOR DD. KLOECKER, G.H. Exosomal microRNA: A diagnostic marker for lung cancer. Clin Lung Cancer 2009; 10: 42-46. http://dx.doi.org/10.3816/CLC.2009.n.006

[19] RUPP AK, RUPP C, KELLER S, BRASE JC, EHEHALT R et al. Loss of EpCAM expression in breast cancer derived serum exosomes: Role of proteolytic cleavage. Gynecol Oncol 2011; 122 (2): 437-446. http://dx.doi.org/10.1016/j. ygyno.2011.04.035

[20] RESNICK KE, ALDER H, HAGAN JP, RICHARDSON DL, CROCE CM et al. The detection of differentially expressed microRNAs from the serum of ovarian cancer patients using a novel real-time PCR platform. Gynecol Oncol 2009; 112: 55-59. http://dx.doi.org/10.1016/j.ygyno.2008.08.036

[21] NAM EJ, YOON HJ, KIM SW, KIM HG, KIM YT et al. MicroRNA expression profiles in serous ovarian carcinoma. Clin Cancer Res 2008; 14: 2690-2695. http://dx.doi. org/10.1158/1078-0432.CCR-07-1731

[22] LOU Y, YANG X, WANG F, CUI Z, HUANG Y. MicroRNA-21 promotes the cell proliferation, invasion and migration abilities in ovarian epithelial carcinomas through inhibiting the expression of PTEN protein. Int J Mol Med 2010; 26: 819-827. http://dx.doi.org/10.3892/ijmm 00000530

[23] XU YZ, XI QH, GE WL, ZHANG XQ. Identification of serum microRNA-21 as a biomarker for early detection and prognosis in human epithelial ovarian cancer. Asian Pacific Journal of Cancer Prevention 2013; 14: 1057-1060. http:// dx.doi.org/10.7314/APJCP.2013.14.2.1057

[24] GUO F, TIAN J, LIN Y, JIN Y, WANG L et al. Serum microRNA-92 expression in patients with ovarian epithelial carcinoma. J Int Med Res 2013; 41: 1456-1461. http://dx.doi. org/10.1177/0300060513487652
[25] ZHENG H, ZHANG L, ZHAO Y, YANG D, SONG F et al. Plasma miRNAs as diagnostic and prognostic biomarkers for ovarian cancer. PLoS ONE 2013; 8 : e77853.

[26] CHUNG YW, BAE HS, SONG JY, LEE JK, LEE NW et al. Detection of microRNA as novel biomarkers of epithelial ovarian cancer from the serum of ovarian cancer patients. Int J Gyn Cancer 2013; 23: 673-9. http://dx.doi.org/10.1097/ IGC.0b013e31828c166d

[27] SURYAWANSHI S, VLAD AM, LIN HM, MANTIA-SMALDONE G, LASKEY $R$ et al. Plasma MicroRNAs as novel biomarkers for endometriosis and endometriosis-associated ovarian cancer. Clin Cancer Res 2013; 19: 1213-1224. http:// dx.doi.org/10.1158/1078-0432.CCR-12-2726

[28] JI T, ZHENG ZG, WANG FM, XU LJ, LI LF et al. Differential microRNA expression by solexa sequencing in the sera of ovarian cancer patients. Asian Pacific Journal of Cancer Prevention 2014; 15: 1739-1743. http://dx.doi.org/10.7314/ APJCP.2014.15.4.1739

[29] SHAPIRA I, OSWALD M, LOVECCHIO J, KHALILI H, MENZIN A et al. Circulating biomarkers for detection of ovarian cancer and predicting cancer outcomes. Br J Cancer 2014; 110: 976-983. http://dx.doi.org/10.1038/ bjc. 2013.795

[30] KAN CWS, HAHN MA, GARD GB, MAIDENS J, HUH JY ET AL. Elevated levels of circulating microRNA-200 family members correlate with serous epithelial ovarian cancer. Bmc Cancer 2012; 12: 627. http://dx.doi.org/10.1186/1471-2407$\underline{12-627}$

[31] TORRES A, TORRES K, PESCI A, CECCARONI M, PASZKOWSKI T et al. Deregulation of miR-100, miR-99a and miR-199b in tissues and plasma coexists with increased expression of mTOR kinase in endometrioid endometrial carcinoma. Bmc Cancer 2012, 12: 369.

[32] TORRES A, TORRES K, PESCI A, CECCARONI M, PASZKOWSKI $T$ et al. Diagnostic and prognostic significance of miRNA signatures in tissues and plasma of endometrioid endometrial carcinoma patients. Int J Cancer 2013; 132: 1633-1645. http://dx.doi.org/10.1002/ijc.27840

[33] JIA W, WU Y, ZHANG Q, GAO G, ZHANG C et al. Identification of four serum microRNAs from a genome-wide serum microRNA expression profile as potential non-invasive biomarkers for endometrioid endometrial cancer. Oncol. Lett 2013; $6: 261-267$.

[34] ZAVESKY L, JANDAKOVA E, TURYNA R, LANGMEIEROVA L, WEINBERGER V ET AL. Evaluation of cell-free urine microRNAs expression for the use in diagnosis of ovarian and endometrial cancers. A pilot study. Pathol Oncol Res 2015, DOI: 10.1007/s12253-015-9914-y. http://dx.doi.org/10.1007/ s12253-015-9914-y

[35] YU J, WANG Y, DONG R, HUANG X, DING S et al. Circulating microRNA-218 was reduced in cervical cancer and correlated with tumor invasion. J. Cancer Res. Clin. Oncol, 2012; 138: 671-674.

[36] CHEN J, YAO D, LI Y, CHEN H, HE C ET AL. Serum microRNA expression levels can predict lymph node metastasis in patients with early-stage cervical squamous cell carcinoma. Int. J. Mol. Med 2013; 32 : 557-567. 
[37] ZHAO S, YAO DS, CHEN JY, DING N. Circulating miRNA20a and miRNA-203 for screening lymph node metastasis in early stage cervical cancer. Genet Test Mol Biomarkers 2013; 17: 631-6. http://dx.doi.org/10.1089/gtmb.2013.0085

[38] IGUCHI H, KOSAKA N, OCHIYA T. Secretory microRNAs as a versatile communication tool. Commun Integr Biol 2010; 3: 478-481. http://dx.doi.org/10.4161/cib.3.5.12693

[39] LO KW, LO YMD, LEUNG SF, TSANG YS, CHAN LYS et al. Analysis of cell-free Epstein-Barr virus associated RNA in the plasma of patients with nasopharyngeal carcinoma. Clin. Chem 1999, 45: 1292-1294.

[40] KOPRESKI MS, BENKO FA, KWAK LW, GOCKE CD. Detection of tumor messenger RNA in the serum of patients with malignant melanoma. Clin Cancer Res 1999; 5: 1961-1965.

[41] LAWRIE CH, GAL S, DUNLOP HM, PUSHKARAN B, LIGGINS AP et al. Detection of elevated levels of tumor-associated microRNAs in serum of patients with diffuse large B-cell lymphoma. Br J Haematol 2008; 141: 672-5. http://dx.doi. org/10.1111/j.1365-2141.2008.07077.x

[42] MITCHELL PS, PARKIN RK, KROH EM, FRITZ BR, WYMAN SK et al. Circulating microRNAs as stable bloodbased markers for cancer detection. Proc Natl Acad Sci USA 2008; 105: 10513-10518. http://dx.doi.org/10.1073/ pnas.0804549105

[43] CHEN X, BA Y, MA L, CAI X, YIN Y et al. Characterization of microRNAs in serum: A novel class of biomarkers for diagnosis of cancer and other diseases. Cell Res 2008; 18: 997-1006. http://dx.doi.org/10.1038/cr.2008.282

[44] PARK NJ, ZHOU H, ELASHOFF D, HENSON BS, KASTRATOVIC DA et al. Salivary microRNA: discovery, characterization, and clinical utility for oral cancer detection. Clin Cancer Res 2009; 15: 5473-5477. http://dx.doi. org/10.1158/1078-0432.CCR-09-0736

[45] WEBER JA, BAXTER DH, ZHANG SL, HUANG DY, HUANG $\mathrm{KH}$ et al. The MicroRNA Spectrum in 12 Body Fluids. Clin Chem 2010; 56 (11): 1733-1741. http://dx.doi.org/10.1373/ clinchem.2010.147405

[46] KOSAKA N, IZUMI H, SEKINE K, OCHIYA T. microRNA as a new immune-regulatory agent in breast milk. Silence 2010, 1: 7 .

[47] ARROYO JD, CHEVILLET JR, KROH EM, RUF IK, PRITCHARD CC et al. Argonaute2 complexes carry a population of circulating microRNAs independent of vesicles in human plasma. Proc Natl Acad Sci USA 2011; 108: 5003-5008. http:// dx.doi.org/10.1073/pnas.1019055108

[48] TURCHINOVICH A, WEIZ L, LANGHEINZ A, BURWINKEL B. Characterization of extracellular circulating microRNA. Nucleic Acids Res 2011; 39: 7223-7233. http:// dx.doi.org/10.1093/nar/gkr254

[49] TURCHINOVICH A, WEIZ L, BURWINKEL B. Extracellular miRNAs: the mystery of their origin and function. Trends Biochem Sci 2012; 37 : 460-465. http://dx.doi.org/10.1016/j. $\underline{\text { tibs.2012.08.003 }}$

[50] MOMI N, KAUR S, RACHAGANI S, GANTI AK, BATRA SK. Smoking and microRNA dysregulation: A cancerous combination. Trends Mol Med 2014; 20 (1): 36-47. http:// dx.doi.org/10.1016/j.molmed.2013.10.005
[51] ZHANG L, HOU D, CHEN X, LI D, ZHU L et al. Exogenous plant MIR168a specifically targets mammalian LDLRAP1: evidence of cross-kingdom regulation by microRNA. Cell Res 2012; 22: 107-126. http://dx.doi.org/10.1038/ cr.2011.158

[52] CHEN X, GAO C, LI HJ, HUANG L, SUN Q ET AL. Identification and characterization of microRNAs in raw milk during different periods of lactation, commercial fluid, and powdered milk products. Cell Res 2010; 20: 1128-1137. http://dx.doi. org/10.1038/cr.2010.80

[53] FRERES P, JOSSE C, BOVY N, BOUKERROUCHA M, STRUMAN I et al. Neoadjuvant Chemotherapy in Breast Cancer Patients Induces miR-34a and miR-122 Expression. J Cell Physiol 2015; 230: 473-481. http://dx.doi.org/10.1002/ jcp. 24730

[54] WITWER KW. Diet-Responsive Mammalian miRNAs Are Likely Endogenous. J Nutr 2014; 144 : 1880-1881. http:// dx.doi.org/10.3945/jn.114.202523

[55] PRITCHARD CC, KROH E, WOOD B, ARROYO JD, DOUGHERTY KJ et al. Blood cell origin of circulating microRNAs: A cautionary note for cancer biomarker studies. Cancer Prev Res 2012; 5: 492-497. http://dx.doi.org/10.1158/19406207.CAPR-11-0370

[56] LATERZA OF, LIM L, GARRETT-ENGELE PW, VLASAKOVA K, MUNIAPPA N et al. Plasma microRNAs as sensitive and specific biomarkers of tissue injury. Clin Chem 2009; 55: 1977-1983. http://dx.doi.org/10.1373/ clinchem.2009.131797

[57] CORSTEN MF, DENNERT R, JOCHEMS S, KUZNETSOVA T, DEVAUX Y et al. Circulating microRNA-208b and microRNA-499 reflect myocardial damage in cardiovascular disease. Circ Cardiovasc Genet 2010; 3: 499-506. http://dx.doi. org/10.1161/CIRCGENETICS.110.957415

[58] LEWIS AP, JOPLING CL. Regulation and biological function of the liver-specific miR-122. Biochem Soc Trans 2010; 38: 1553-1557. http://dx.doi.org/10.1042/BST0381553

[59] ZHANG Y, JIA Y, ZHENG R, GUO Y, WANG Y et al. Plasma microRNA-122 as a biomarker for viral-, alcohol-, and chemical-related hepatic diseases. Clin. Chem 2010; 56: 1830-1838.

[60] PENG WZ, MA R, WANG F, YU J, LIU ZB. Role of miR$191 / 425$ cluster in tumorigenesis and diagnosis of gastric cancer. Int J Mol Sci 2014; 15: 4031-4048. http://dx.doi. org/10.3390/ijms15034031

[61] CHEN SY, WANG Y, TELEN MJ, CHI JT. The genomic analysis of erythrocyte microRNA expression in sickle cell diseases. PLoS ONE 2008, 3 (6): e2360.

[62] BRUCHOVA H, MERKEROVA M, PRCHAL JT. Aberrant expression of microRNA in polycythemia vera. Haematologica 2008; 93: 1009-1016. http://dx.doi.org/10.3324/ haematol.12706

[63] MERKEROVA M, BELICKOVA M, BRUCHOVA H. Differential expression of microRNAs in hematopoietic cell lineages. Eur J Haematol 2008; 81: 304-310. http://dx.doi. org/10.1111/j.1600-0609.2008.01111.x

[64] LANDRY P, PLANTE I, OUELLET DL, PERRON MP, ROUSSEAU G et al. Existence of a microRNA pathway in anucleate 
platelets. Nat Struct Mol Biol 2009; 16: 961-966. http://dx.doi. org/10.1038/nsmb.1651

[65] WILLEIT P, ZAMPETAKI A, DUDEK K, KAUDEWITZ D, KING A et al. Circulating MicroRNAs as novel biomarkers for platelet activation. Circ Res 2013, 112: 595-600.

[66] SMIGIELSKA-CZEPIEL K, VAN DEN BERG A, JELLEMA P, VAN DER LEI RJ, BIJZET J et al. Comprehensive analysis of miRNA expression in T-cell subsets of rheumatoid arthritis patients reveals defined signatures of naive and memory Tregs. Genes Immun 2014; 15: 115-125. http://dx.doi.org/10.1038/ gene.2013.69
[67] BELVER L, PAPAVASILIOU FN, RAMIRO AR. MicroRNA control of lymphocyte differentiation and function. Curr Opin Immunol 2011;23:368-373. http://dx.doi.org/10.1016/j. coi.2011.02.001

[68] MA X, ZHOU J, ZHONG Y, JIANG L, MU P ET AL. Expression, regulation and function of MicroRNAs in multiple sclerosis. Int J Med Sci 2014; 8: 810-818. http://dx.doi. org/10.7150/ijms.8647

[69] DI LEVA G, CROCE CM. Roles of small RNAs in tumor formation. Trends in Molecular Medicine 2010; 16: 257-267. http://dx.doi.org/10.1016/j.molmed.2010.04.001 